\title{
MODEL PEMBELAJARAN DISCOVERY LEARNING SEBAGAI METODE UNTUK MENINGKATKAN PRESTASI BELAJAR
}

\author{
Siti Ratna Syari \\ Universitas Pendidikan Indonesia \\ sitiratnasari@student.upi.edu \\ B Lena Nuryanti S \\ Universitas Pendidikan Indonesia \\ lenanuryanti@upi.edu
}

\begin{abstract}
The base student achievement was the background of this study. The ignoble scores on student achievement, especially in entrepreneurship subject was influenced by the external and internal factors. Learning model could have developed by teachers in the school environment that certainly have a profound influence on learning achievement. SMK Negeri 1 Bandung teachers apply the discovery learning model in entrepreneurship subjects to improve learning achievement of learners. The purpose of this study is to describe: 1) the application of the discovery learning model in class XI SMK Negeri 1 Bandung, 2) learning achievement in class XI AP and UPW SMK Negeri 1 Bandung, 3) The amount of influence discoveries learning model on achievement learning in class XI AP and UPW of SMK Negeri 1 Bandung.

Discovery learning model as the independent variable $(X)$, and the dependent variable is learning achievement $(Y)$ with descriptive and verification analysis. The method used in this research was explanatory survey method with simple random sampling technique with 124 respondents used linear regression technique.

The findings in this study are as follows: 1) the application of learning model discovery learning in class XI AP and UPW in either category, 2) learning achievement in AP classes and UPW in the high category, 3) learning achievement positively influenced by discovery learning model with a coefficient of determination $21.3 \%$. The Result based on the research, discovery learning model with indicators and different objects recommended as a basis for other studies.
\end{abstract}

Keywords: discovery learning model, academic achievement

Indonesia merupakan negara berkembang, dikatakan berkembang karena negara Indonesia masih memiliki kualitas hidup yang rendah. Akibat rendahnya kualitas hidup, tingkat penghasilan masyarakat pun berdampak buruk, sehingga masyarakat mengalami kesulitan untuk memenuhi kebutuhan pokok, pendidikan, dan kesehatan. Guna meningkatkan kualitas hidup, bangsa Indonesia harus lebih meningkatkan kualitas pendidikan.

Pendidikan merupakan proses pengembangan daya nalar, keterampilan, dan moralitas yang dilakukan dengan usaha sadar dan terencana untuk mewujudkan suasana belajar dan proses pembelajaran berlangsung secara efektif. Menurut Undang-Undang Sistem Pendidikan Nasional No.20 Tahun 2003 Pasal 3 tentang fungsi dan tujuan pendidikan adalah: Pendidikan nasional berfungsi mengembangkan kemampuan dan membentuk watak serta peradaban bangsa yang bermartabat dalam rangka mencerdaskan kehidupan bangsa, bertujuan untuk berkembangnya potensi peserta didik agar menjadi manusia yang beriman dan bertaqwa kepada
Tuhan Yang Maha Esa, berahlak mulia, sehat berilmu, cakap, kreatif, mandiri, dan menjadi warga negara yang demokratis serta bertanggung jawab.

Permasalahan yang terjadi pada pendidikan di Indonesia salah satunya adalah rendahya prestasi belajar siswa. Prestasi belajar merupakan tolak ukur keberhasilan suatu proses pembelajaran dengan kata lain prestasi belajar yang diperoleh peserta didik mencerminkan tingkat penguasaan peserta didik terhadap materi yang diajarkan. Dampak dari rendahnya prestasi belajar siswa, menjadikan hasil evaluasi yang dilaksanakan beberapa sekolah khususnya pada Sekolah Menengah Kejuruan (SMK).

Pendidikan kewirausahaan yang diberikan di Sekolah Menengah Kejuruan (SMK), akan membentuk pola pikir serta paradigma peserta didik yang awalnya adalah lulus sekolah mencari pekerjaan, menjadi lulus sekolah menciptakan lapangan pekerjaan. Dengan adanya pendidikan kewirausahaan di SMK, diharapkan lulusannya mampu menciptakan lapangan kerja sebagai hasil dari sikap dan mentalitas kemandirian yang nantinya akan bermanfaat bagi dirinya, orang lain, 
dan terutama dalam meningkatkan pembangunan bangsa dalam meminimalisir tingkat penganguran yang diakibatkan menipisnya lapangan pekerjaan. (http://dikmen.kemdikbud.go.id/html/index diakses tanggal 20 Januari 2015 pukul 20.05)

Terdapat 16 Sekolah Menengah Kejuruan (SMK) Negeri di Kota Bandung yang terdiri dari beberapa bidang keahlian diantaranya Bisnis dan manajemen, Teknik, Perhotelan, Kesenian dan lainnya. Salah satu SMK Negri Bisnis dan manajemen di Kota Bandung yaitu SMK Negeri 1 Bandung yang didalam nya terdapat empat jurusan, diantaranya Akutansi, Pemasaran, Usaha Perjalan Wisata dan Administrasi Perkantoran.

Dalam peraturan Mendiknas No 20 tahun 2007 tentang Standar Penilaian Pendidikan menyebut bahwa ulangan tengah semester, ulangan akhir semester, dan ulangan kenaikan kelas dilakukan oleh pendidik di bawah koordinasi satuan pendidikan. Selain itu, ada jenis ulangan yang dinamakan ujian sekolah/madrasah dan ujian nasional (UN). Untuk mengukur keberhasilan proses pencapain kompetensi peserta didik, perlu ditetapkan Kriteria Ketuntasan Minimal (KKM).

Berdasarkan hasil pra penelitian melalui observasi dan wawancara ditemukan beberapa indikasi awal yang menyatakan adanya masalah mengenai prestasi belajar siswa pada mata pelajaran kewirausahaan. Berdasarakan data nilai rata-rata Ujian Tengah Semester (UTS) Ganjil SMK Negri 1 Bandung pada mata pelajaran kewirausahaan dikelas XI Usaha Perjalanan Wisata dan Administrasi Perkantoran. Hal ini dapat dilihat pada tabel berikut ini :

TABEL 1.1

RATA-RATA NILAI HASIL UJIAN TENGAH SEMESTER GANJIL PESERTA DIDIK KELAS XI SMKN 1 BANDUNG

TAHUN AJARAN 2014/2015

\begin{tabular}{|c|c|c|c|}
\hline No & Kelas & $\begin{array}{c}\text { Nilai Rata- } \\
\text { Rata UTS }\end{array}$ & KKM \\
\hline $\mathbf{1}$ & XI AP 1 & 76,80 & $\mathbf{7 5}$ \\
\hline $\mathbf{2}$ & XI AP 2 & 76,36 & $\mathbf{7 5}$ \\
\hline $\mathbf{3}$ & XI AP 3 & 74,80 & $\mathbf{7 5}$ \\
\hline $\mathbf{4}$ & XI UPW 1 & 72,71 & $\mathbf{7 5}$ \\
\hline $\mathbf{5}$ & XI UPW 2 & 73,88 & $\mathbf{7 5}$ \\
\hline
\end{tabular}

Sumber : data diolah dari rekap nilai ujian tengah semester

Berdasarkan Tabel 1.1 Mata pelajaran kewirausahaan yang diajarkan semakin menambah pengetahuan kewirausahaan siswa SMK tentang wirausaha. Adapun nilai KKM yang harus di tempuh oleh peserta didik pada mata pelajaran kewirausahaan adalah 75. Maka dapat dilihat dari tabel tersebut bahwa masih banyak peserta didik yang mengalami masalah dalam prestasi belajar. Hal ini bisa dilihat dari rendahnya nilai ujian tengah semester kelas XI UPW 1 dan XI UPW 2 dari seluruh kelas XI Usaha perjalanan Wisata dan Administrasi Perkantoran yang mengikuti pembelajaran kewirausahaan.

Berikut hasil rekapitulasi ujian tengah semester kelas XI Usaha perjalanan wisata dan andministrasi perkantoran di SMKN 1 Bandung :

TABEL 1.2

REKAPITULASI NILAI UJIAN TENGAH SEMESTER KELAS XI UPW DAN AP PADA MATA PELAJARAN KEWIRAUSAHAAN SMKN 1 BANDUNG TAHUN AJARAN 2014/2015

\begin{tabular}{|c|c|c|c|c|c|c|c|}
\hline \multirow{2}{*}{ No. } & \multirow{2}{*}{ Kelas } & \multirow{2}{*}{ KKM } & \multicolumn{2}{|c|}{ Nilai } & \multirow{2}{*}{ Jumlah } & $\begin{array}{c}\text { Presentase } \\
\text { di Bawah } \\
\text { KKM }\end{array}$ & $\begin{array}{c}\text { Presentase } \\
\text { di Atas } \\
\text { KKM }\end{array}$ \\
\hline 1 & XI AP 1 & 75 & 9 & 27 & 36 & $\mathbf{2 5 \%}$ & $75 \%$ \\
\hline $\mathbf{2}$ & XI AP 2 & 75 & 7 & 29 & 36 & $19 \%$ & $\mathbf{3 1 \%}$ \\
\hline 3 & XI AP 3 & 75 & 17 & 19 & 36 & $47 \%$ & $53 \%$ \\
\hline 4 & XI UPW 1 & 75 & 25 & 10 & 35 & $72 \%$ & $28 \%$ \\
\hline 5 & XI UPW 2 & 75 & 22 & 14 & 36 & $61 \%$ & $39 \%$ \\
\hline
\end{tabular}

Sumber : data diolah dari rekap nilai ujian tengah semester

Data tersebut memberikan informasi bahwa banyak siswa yang mengikuti ulangan perbaikan atau remedial. Pada mata pelajaran Kewirausahaan, pada tahun pelajaran 2014 semester ganjil terdapat 80 siswa yang harus mengikuti remedial. Hal ini menerangkan bahwa kegiatan pembelajaran pada mata pelajaran Kewirausahaan memiliki permasalahan dalam belum optimalnya ketercapaian hasil belajar siswa.

Melihat fenomena yang menyangkut prestasi belajar siswa dalam mata pelajaran kewirausahaan yang masih rendah hal ini menunjukkan tujuan pembelajaran kewirausahaan di SMK Negri 1 Bandung pada kelas XI jurusan Usaha Perjalanan Wisata (UPW) dan Administrasi Perkantoran (AP) belum terwujud.

Rendahnya nilai pada prestasi belajar siswa khususnya dalam mata pelajaran kewirausahaan dipengaruhi oleh beberapa faktor. Menurut Slameto (2003:54) faktor intern dan faktor ekstern, faktor intern terdiri dari faktor jasmaniah, faktor psikologis dan faktor kelelahan. Faktor ekstern terdiri dari faktor keluarga dan faktor sekolah, faktor sekolah yang meliputi guru, model pembelajaran, kurikulum, relasi guru dengan peserta didik, disiplin sekolah, standar pengajaran, keadaan gedung, dan tugas rumah. Melalui faktor eksternal inilah kemampuan berpikir yang dimiliki oleh seseorang siswa dapat terlihat.

Guru mempunyai peranan yang penting dalam mewujudkan tercapainya tujuan pembelajaran kewirausahaan. Seorang guru bukan hanya memberikan pengetahuan kepada siswa, namun guru harus mampu menciptakan kondisi dan situasi yang memungkinkan pembelajaran berlangsung secara aktif. Salah satunya dengan memperhatikan model pembelajaran yang digunakan. 


\section{StrategiC}

Kompetensi guru merupakan spesifikasi atau kriteria kompetensi yang harus dimiliki oleh setiap guru. Menurut Undang-undang Republik Indonesia No 14 tahun 2005 tentang guru dan dosen pasal 10 ayat 1 menyebutkan Kompetensi guru meliputi kompetensi pedagogik, kompetensi kepribadian, kompetensi sosial, dan kompetensi professional yang diperoleh melalui pendidikan profesi. Dimana seorang guru yang profesional dituntut dapat memahami dan memiliki keterampilan dalam mengembangkan berbagai model pembelajaran yang efektif, kreatif dan menyenangkan sebagaimana yang telah diisyaratkan dalam kurikulum 2013.

Model pembelajaran pada dasarnya merupakan bentuk pembelajaran yang tergambar dari awal sampai akhir yang disajikan guru untuk mempermudah proses pembelajaran. Model pembelajaran yang digunakan pada mata pelajaran kewirausahaan sebaiknya lebih bersifat kontekstual, sehingga peserta didik memiliki keterampilan pemahaman teori yang baik serta melakukan riset pasar atau tugas lapangan sebagai pengalaman untuk menambah motivasi berwirausaha.

(http://strategipembelajaran.pusku.com/2014/02. diakses pada tanggal 20 maret 2015 pukul 21.15)

Terdapat beberapa model pembelajaran yang disarankan untuk digunakan dalam pembelajaran Sekolah Menengah Kejuruan (SMK) pada kurikulum 2013 yaitu Project Based Learning, Problem Based Learning dan Discovery Learning.

Menurut Erni Arinawati (2014:8) menyebutkan bahwa model pembelajaran discovery learning terbukti mampu meningkatkan keaktifan dikelas, kemampuan berfikir kreatif, memecahkan masalah, serta meningkatkan prestasi belajar siswa.

Model pembelajaran discovery learning menempatkan peserta didik sebagai subyek belajar yang aktif yang mengedepankan unsur kreativitas peserta didik dimana peserta didik dituntut untuk dapat mengeksplorasi kemampuannya sehingga dapat menemukan sendiri makna dari sebuah materi yang diajarkan. Pada model pembelajaran ini peserta didik dilibatkan dalam kegiatan intelektual, sikap, keterampilan psikomotorik dan menuntut peserta didik memproses pengalaman belajar menjadi suatu yang bermakna dalam kehidupan nyata sedangkan guru hanya menjadi fasilitator yang mengarahkan peserta didik untuk mencari tahu, mengkaji, dan mengobservasi halhal yang berkaitan dengan materi kemudian disimpulkan sampai didapat pemahaman yang mendalam dari hasil pemikirannya sendiri. Hal ini sesuai dengan tujuan pembelajaran kewirausahaan dimana siswa di tuntut untuk aktif serta berpikir kreatif.
Dengan demikian dapat dipahami untuk mencapai tujuan pembelajaran, seorang guru hendaknya memiliki kemampuan mengorganisasikan model pembelajaran mulai dari memilih model pembelajaran yang sesuai, hingga dapat mengembangkan keterkaitan materi pembelajaran dengan konteks lingkungan kehidupan siswa. Melalui adanya pendidikan kewirausahaan menggunakan pembelajaran discovery learning kemampuan siswa dapat dikembangkan sebagai bekalnya untuk memulai aktivitas bisnis atau memulai pekerjaan bila mereka lulus nantinya.

Berdasarkan uraian pada latar belakang penelitian di atas, maka dipandang perlu untuk melakukan penelitian yang dituangkan dalam judul "Pengaruh Model Pembelajaran Discovery Learning Terhadap Prestasi Belajar" (Survei Pada Mata Pelajaran Kewirausahaan Kelas XI Usaha Perjalanan Wisata dan Administrasi Perkantoran SMK Negeri 1 Bandung).

\section{KAJIAN TEORI}

Gagne dalam Kokom Komalasari (2011:2) mendefinisikan belajar sebagai suatu proses perubahan tingkah laku yang meliputi perubahan kecendrungan manusia seperti sikap, minat, atau nilai dan perubahan kemampuannya yakni peningkatan kemampuan untuk melakukan berbagai jenis performance (kinerja).

Proses belajar mengajar menurut Nana Sudjana (2002:1) Merupakan pelaksanaan kurikulum suatu lembaga pendidikan, agar mampu mempengaruhi siswa untuk mencapai tujuan yang telah ditentukan.

Proses belajar mengajar terjadi jika adanya interaksi perilaku mengajar pada pihak guru dan perilaku belajar pada pihak siswa tidak berlangsung dalam satu arah melainkan adanya timbal-balik. Tujuan merupakan titik temu dan bersifat mengikat dan mengarahkan aktifitas kedua belah pihak. Tujuan tersebut dinilai dan dievaluasi agar mengetahui sejauh apa ketercapaian tujuan bersama. Berdasarkan penjelasan tersebut proses belajar mengajar tidak terlepas dari faktor guru dan model pembelajaran yang baik, proses belajar mengajar akan berjalan dengan baik jika guru menggunakan model pembelajaran yang baik juga. Menurut Suyono dan Hariyanto (2012:218) Model pembelajaran merupakan komponen utama proses pembelajaran yang didalamnya terdapat pendekatan, strategi, metode, tehnik dan taktik yang tersistematik kedalam sebuah model untuk mencapai tujuan pembelajaran.

Menurut Aunurrahman (2012:146) model pembelajaran dapat dimaknai sebagai perangkat rencana atau pola yang dapat dipergunakan untuk merancang bahan-bahan pembelajaran serta membimbing aktivitas pembelajaran di kelas atau 
di tempat-tempat lain yang melaksanakan aktivitas-aktivitas pembelajaran. Model pembelajaran akan digunakan oleh guru sebagai pedoman yang dianggap paling sesuai dengan tujuan, bahan dan sarana pendukung dalam melakukan tugas-tugas mengajar guru. Oleh karena itu perlu melakukan pemilihan model pembelajaran yang tepat dalam setiap kondisi pembelajaran.

Dalam implementasi kurikulum 2013, digunakan sebuah pendekatan yang mengacu pada pemahaman mendalam seorang siswa terhadap materi yang diajarkan. Pendekatan ini disebut pendekatan saintifik yaitu pembelajaran yang mengarahkan siswa untuk terlibat dalam mengkonstruk konsep, hukum atau prinsip melalui tahapan mengamati, menanya, menalar, mencoba, dan mengkomunikasikan.

Dalam pembelajaran menggunakan kurikulum 2013, ada beberapa model pembelajaran yang dapat diterapkan, diantaranya Pembelajaran Berbasis Masalah (Problem Based Learning), Pembelajaran Berbasis Proyek (Project Based Learning), dan Pembelajaran Penemuan (Discovery learning).

Model Discovery learning adalah teori belajar yang didefinisikan sebagai proses pembelajaran yang terjadi bila pelajar tidak disajikan dengan pelajaran dalam bentuk finalnya, tetapi diharapkan mengorganisasi sendiri. Sebagaimana pendapat Jerome Bruner "Discovery learning can be defined as the learning that takes place when thestudent is not presented with subject matter in the final form, but rather is required to organize it him self" (Lefancois dalam Emetembun, 1986:103). Model Discovery learning adalah memahami konsep, arti, dan hubungan, melalui proses intuitif untuk akhirnya sampai kepada suatu kesimpulan (Budiningsih 2005:43). (Sumber: http://ariefhistoria.blogspot.co.id/)

Strategi pembelajaran ini yang dikembangkan pertama kali oleh Jerome Bruner menitik beratkan pada kemampuan peserta didik dalam menemukan sesuatu melalui proses inquiry (penelitian) secara terstruktur dan terorganisir dengan baik. Sejalan dengan pendapat Masarudin Siregar dalam Muhammad Takdir (2012:30) bahwa discovery by learning adalah proses pembelajaran untuk menemukan sesuatu yang baru dalam kegiatan belajar mengajar. Proses belajar dapat menemukan sesuatu apabila pendidik menyusun terlebih dahulu beragam materi yang akan disampaikan, selanjutnya mereka dapat melakukan proses untuk menemukan sendiri berbagai hal penting terkait dengan kesulitan dalam pembelajaran.

Prestasi belajar menurut Benyamin S. Bloom (dalam Nurman, 2006 : 36) prestasi belajar merupakan hasil perubahan tingkah laku yang meliputi tiga ranah kognitif, afektif dan psikomotor. Dalam proses pembelajaran upayaupaya untuk meningkatkan penguasaan materi yang akan mendukung prestasi belajar siswa sesuai dengan tujuan pembelajaran penting untuk dilakukan, akan tetapi peningkatan penguasaan materi tidak akan berhasil tanpa adanya dukungan dari faktor instrumental belajar. Dari sekian banyak instrumen yang mempengaruhi proses pembelajaran, guru merupakan salah satu instrumen yang sangat berperan.

Berdasarkan uraian tersebut dapat diketahui bahwa Discovery Learning dapt mempengaruhi Prestasi Belajar. Adapun paradigma dalam penelitian ini yaitu:

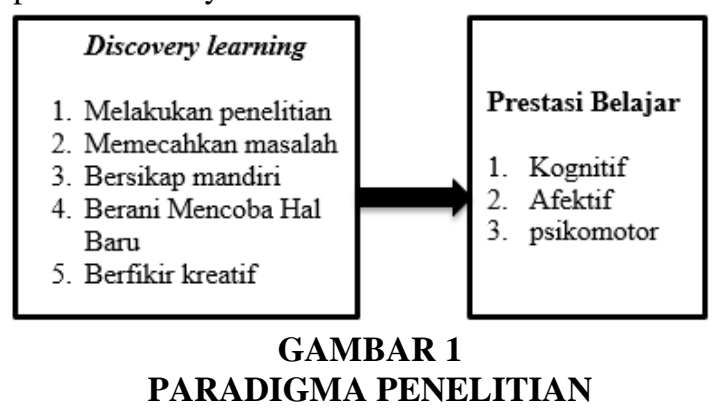

\section{METODE}

Penelitian yang dilakukan yaitu penelitian deskriptif dan verifikatif yang dilaksanakan melalui pengumpulan data di lapangan, maka metode yang digunakan dalam penelitian ini adalah survey.

Dalam penelitin ini hanya terdapat dua variabel yang hanya terdiri dari variabel bebas (independent variable) yaitu model pembelajaran discovery learning (X) sedangkan variabel terikat (dependent variable) adalah prestasi belajar (Y).

Penelitian ini dilakukan di SMK Negeri 1 Bandung. Berdasarkan kurun waktu penelitian yang dilaksanakan pada kurun waktu kurang dari satu tahun, maka metode penelitian yang digunakan adalah cross sectional method. Menurut Husein Umar (2008:45) mengemukakan bahwa, "Pendekatan cross sectional yaitu metode penelitian dengan cara mempelajari objek dalam kurun waktu tertentu atau tidak berkesinambungan dalam jangka panjang".

Populasi dalam penelitian ini adalah siswa kelas XI UPW dan AP dengan jumlah $\mathrm{N}=179$ orang. Dalam penelitian ini jumlah sampel ditentukan melalui teknik penarikan sampel dengan teknik simple random sampling atau pengambilan sampel secara acak. Dalam pengambilan sampel ini digunakan taraf kesalahan sebesar 5\%. Adapun rumus yang digunakan yaitu sebagai berikut: 


\section{StrategiC}

$$
\mathrm{n}=\frac{N}{1+(N e)^{2}}
$$

Keterangan:

n : Ukuran Sampel

$\mathrm{N} \quad$ : Ukuran Populasi

e :Kelonggaran ketidaktelitian karena kesalahan sampel yang dapat ditolelir

Adapun perhitungan jumlah sampel yang digunakan dalam penelitian ini adalah:

$\mathrm{N}=179 \quad \mathrm{e}=0,05$

Maka:

Berdasarkan perhitungan tersebut, maka dalam penelitian ini diambil sampel sebanyak 124 siswa.

\section{HASIL DAN PEMBAHASAN}

\section{Pembahasan Deskriptif}

a. Discovery Learning

Berdasarkan hasil penelitian yang bersifat empirik mengenai penerapan model pembelajaran discovery learning pada pada mata pelajaran kewirausahaan kelas XI AP dan UPW SMK Negeri 1 Kota Bandung dihasilkan temuan bahwa indikator model pembelajaran discovery learning yaitu bersikap mandiri telah memberikan kontribusi yang cukup tinggi bagi peserta didik dalam mencapai pembelajaran discovery learning.

b. Prestasi Belajar

Prestasi belajar pada peserta didik kelas XI AP dan UPW SMK Negeri 1 Kota Bandung yang mendapat skor tertinggi yaitu dalam indikator kognitif dengan pernyataan bahwa setiap keberhasilan dapat diraih dengan kerja keras dalam mencapai prestasi belajar.

\section{Pembahasan Verifikatif}

Dengan menggunakan program SPSS 21.0 for Windows, diperoleh hasil koefisien regresi sebagai berikut:

\section{MODEL REGRESI LINEAR BERGANDA} Coefficients $^{\mathrm{a}}$

\begin{tabular}{|c|c|c|c|c|c|}
\hline Model & \multicolumn{2}{|c|}{$\begin{array}{c}\text { Unstandardized } \\
\text { Coefficients }\end{array}$} & $\begin{array}{c}\text { Standa } \\
\text { rdized } \\
\text { Coeffi } \\
\text { cients }\end{array}$ & $\mathrm{t}$ & Sig. \\
\cline { 2 - 5 } & $\mathrm{B}$ & $\begin{array}{c}\text { Std. } \\
\text { Error }\end{array}$ & Beta & & \\
\hline $\begin{array}{c}\text { (Consta } \\
\mathrm{nt})\end{array}$ & $\begin{array}{c}35015 . \\
435\end{array}$ & $\begin{array}{c}4454.0 \\
87\end{array}$ & & 5.165 & .000 \\
$\begin{array}{c}\text { Discove } \\
\text { ry } \\
\text { Learnin } \\
\mathrm{g}\end{array}$ & .221 & .031 & .461 & 5.742 & .000 \\
\hline
\end{tabular}

a. Dependent Variable: Prestasi Belajar

Sumber: Hasil Pengolahan Data, 2015.

$$
\mathrm{Y}=35015,435+0,221 \mathrm{X}
$$

Berdasarkan persamaan regresi linear sederhana di atas, konstanta sebesar 35015,435 menyatakan bahwa jika tidak ada model discovery learning, maka besarnya prestasi belajar sebesar 35015,435 . Koefesien regresi sebesar 0,221 satu satuan nilai artinya setiap terjadi peningkatan model discovery learning akan meningkatkan prestasi belajar sebesar 0,221 satu satuan nilai dan sebaliknya, jika terjadi penurunan prestasi belajar, model discovery learning akan menurunkan prestasi belajar sebesar 0,221 satu satuan nilai.

Hubungan antara orientasi kewirausahaan terhadap kinerja usaha diperoleh dari model summary yang dijelaskan secara rinci berikut:

TABEL 4

Model Summary ${ }^{b}$

\begin{tabular}{|l|c|r|r|r|}
\hline Model & R & R Square & Adjusted R Square & $\begin{array}{r}\text { Std. Error of } \\
\text { the Estimate }\end{array}$ \\
\hline 1 & $.461^{2}$ & .213 & .206 & 7143.694 \\
\hline
\end{tabular}

Sumber: Hasil Pengolahan Data, 2015.

Dari tabel di atas dapat dihitung nilai koefisien determinasi berikut ini.

$\mathrm{KD}=0,213 \times 100 \%$

$\mathrm{KD}=21,3 \%$

Hasil perhitungan di atas menunjukkan bahwa besarnya KD (koefisien determinasi) adalah $21,3 \%$ yang berarti $21,3 \%$ prestasi belajar dipengaruhi oleh model discovery learning dan sisanya yaitu sebesar $78,7 \%$ dipengaruhi oleh faktor lain yang tidak diteliti.dalam penelitian ini.

\section{Uji Hipotesis}

TABEL 5

HASIL UJI t ( $t$-Test)

\begin{tabular}{|c|c|c|c|c|c|}
\hline \multirow[t]{2}{*}{ Model } & \multicolumn{2}{|c|}{$\begin{array}{l}\text { Unstandardized } \\
\text { Coefficients }\end{array}$} & $\begin{array}{l}\text { Standardi } \\
\text { zed }\end{array}$ & \multirow[t]{2}{*}{$\mathrm{T}$} & \multirow[t]{2}{*}{ Sig } \\
\hline & B & $\begin{array}{l}\text { Std. } \\
\text { Error }\end{array}$ & Beta & & \\
\hline $\begin{array}{l}\text { (Consta } \\
\text { nt) }\end{array}$ & $\begin{array}{r}35015.4 \\
35\end{array}$ & $\begin{array}{r}4454.0 \\
87\end{array}$ & & $\begin{array}{r}5.16 \\
5\end{array}$ & $\begin{array}{r}.00 \\
0\end{array}$ \\
\hline $\begin{array}{l}1 \text { Discove } \\
\text { ry } \\
\text { Learnin } \\
\mathrm{g}\end{array}$ & .221 & .031 & .461 & $\begin{array}{r}5.74 \\
2\end{array}$ & $\begin{array}{r}.00 \\
0\end{array}$ \\
\hline
\end{tabular}
Coefficients $^{\mathrm{a}}$

a. Dependent Variable: Kinerja Usaha

Sumber: Hasil Pengolahan Data, 2015.

Perhitungan uji-t dengan bantuan program SPSS 21.0 for windows diperoleh nilai $t_{\text {hitung }}$ sebesar 5,742 dengan tingkat signifikansi $5 \%$. Dibandingkan dengan nilai $t_{\text {tabel, }}$, perolehan nilai $\mathrm{t}_{\text {hitung }}$ memiliki angka yang lebih besar daripada nilai $\mathrm{t}_{\text {tabel }}(5,742>1.657)$, maka dapat diambil keputusan bahwa hipotesis nol $\left(\mathrm{H}_{0}\right)$ ditolak dan $\mathrm{H}_{\mathrm{a}}$ diterima. Artinya bahwa terdapat pengaruh positif model discovery learning terhadap prestasi belajar. 


\section{KESIMPULAN}

Berdasarkan uraian-uraian teori, hasil penelitian dan pengujian analisis regresi yang dilaksanakan mengenai pengaruh model discovery learning terhadap prestasi belajar peserta didik kelas XI AP dan UPW SMK Negeri 1 Kota Bandung pada mata pelajaran kewirausahaan, maka dapat diambil kesimpulan sebagai berikut:

1. Tanggapan peserta didik pada penerapan model discovery learning yang diterapkan oleh guru kewirausahaan kelas XI SMK Negeri 1 Kota Bandung berada pada kategori hampir seluruhnya yang artinya baik. Hal ini dapat dilihat dari indikator paling tinggi hingga yang terendah. Indikator yang memperoleh skor tertinggi yaitu bersikap mandiri dengan perolehan skor $78,0 \%$. Sedangkan indikator yang memiliki penilaian paling rendah yaitu indikator berfikir kreatif dengan skor 67,7\%.

2. Prestasi Belajar pada peserta didik kelas XI AP dan UPW SMK Negeri 1 Kota Bandung berada pada kategori tinggi. Hal tersebut menunjukkan bahwa prestasi belajar pada peserta didik kelas XI AP dan UPW SMK Negeri 1 Kota Bandung sudah baik, hal ini dapat dilihat dari indikator paling tinggi hingga terendah yaitu indikator kognitif yang mendapatkan tanggapan responden paling tinggi sebesar $78,5 \%$, sedangkan indikator yang mendapatlkan skor terendah yaitu indikator afektif sebesar $66,5 \%$.

3. Penerapan model pembelajaran discovery learning yang dilakukan oleh guru kewirausahaan di SMK Negeri 1 Kota Bandung berpengaruh positif terhadap prestasi belajar sebesar $21,3 \%$ dengan tingkat korelasi yang sedang.

\section{REKOMENDASI}

1. Model Pemebelajaran discovery learning di kelas XI SMK Negeri 1 Bandung dapat ditingkatkan dengan meningkatkan kemampuan guru mendesain model pembelajaran discovery learning dalam membuat peserta didik lebih berpikir kreatif dengan mengikuti banyak pelatihan dan pendidikan sehingga mampu menghasilkan peserta didik dengan prestasi belajar yang baik, serta mampu berfikir kreatif sehingga peserta didik dapat memahami suatu fenomena atau permasalahan dari berbagai sisi tidak hanya dari satu atau dua sisi tertentu saja.

2. Prestasi belajar di SMK Negeri 1 Bandung dapat ditingkatkan pada aspek afektif yang mencakup watak perilaku, sikap, minat, dan motivasi peserta didik untuk mencapai tujuan pembelajaran. Peserta didik perlu memiliki sikap positif terhadap proses pembelajaran sehingga pencapaian hasil belajar bisa maksimal.

3. Hasil penelitian ini menyatakan bahwa model pembelajaran discovery learning berpengaruh positif terhadap prestasi belajar. Maka penulis merekomendasikan agar SMK Negeri 1 Bandung tetap memakai model pembelajaran discovery learning dan penelitian ini diharapkan dapat dijadikan masukan atau rujukan data empirik dalam melakukan penelitian selanjutnya yang berkaitan dengan model pembelajaran discovery learning dalam kegiatan belajar mengajar.

\section{DAFTAR PUSTAKA}

Arinawati, Erni (2014). Pengaruh Model Pembelajaran Discovery Learning Terhadap Prestasi Belajar Matematika Ditinjau Dari Motivasi Belajar. Skripsi, UPI Bandung: Tidak diterbitkan.

Aunurrahman (2012). Belajar dan Pembelajaran. Bandung : Alfabeta.

Illahi, Mohammad Takdir. (2012). Pembelajaran Discovery Startegy dan Mental Vocational Skill. Jogjakarata: DIVA Press.

Kementerian Pendidikan dan Kebudayaan. 2014. Peraturan Menteri Pendidikan dan Kebudayaan Republik Indonesia nomor 103 tahun 2014 tentang Kurikulum 2013 Sekolah Menengah Atas/Madrasah Aliyah

Kokom, Komalasari (2011). Pembelajaran Kontekstual Konsep dan Aplikasi. Bandung: Refika Aditama.

Nurman, Muhammad. (2006)."Pengaruh Penggunaan Metode Pembelajaran Inkuiri dan Ekspositori Terhadap Sikap Politik Berdemokrasi dan Prestasi belajar Siswa Pada Pembelajaran PPKn di SMA (Studi Eksperimen tentang Pengaruh Metode Pembelajaran Terhadap Sikap Politik Berdemokrasi dan Prestasi Belajar PPKn Siswa di SMA NW Pancor - Lombok Timur). Tesis (tidak diterbitkan) Program Pascasarjana IKIP Negeri Singaraja.

Slameto. (2003). Belajar dan Faktor-faktor yang Mempengaruhinya. Jakarta: Rineka Cipta.

Sudjana, Nana. (2002). Dasar-dasar Proses Belajar Mengajar. Bandung: Sinar Baru.

Suyono \& Hariyanto. (2012). Belajar dan Pembelajaran. Teori dan Konsep Dasar. Surabaya:Rosda.

Umar, Husain (2008). Metode Penelitian Pendidikan Untuk Skripsi dan Tesis Bisnis 
edisi ke 2. Jakarta : PT. Raja Grafindo Prasada

Undang-Undang. (2003). Undang-Undang RI Nomor 20, Tahun 2003, tentang Sistem pendidikan nasional.

Undang-Undang. (2005). Undang-Undang RI Nomor 14, Tahun 2005, tentang Guru dan dosen.

Faizah, Anni (2015). Pendekatan, Strategi, Metode, Model, Teknik dan Taktik Pembelajaran.

http://strategipembelajaran.pusku.com/20 15/02/pendekatan-strategi-metode-modelteknik-dan-taktik-pembelajaran-apendekatan-pembelajaran-pendekatanpembelajaran-adalah-sudut-pandangkita-terhadap-proses-suatupembelajaran-yang-merujuk-pada/. diakses pada tanggal 20 maret 2015 pukul 21.15 .

http://dikmen.kemdikbud.go.id/html/index diakses tanggal 20 Januari 2015 pukul 20.05

http://ariefhistoria.blogspot.co.id/, diakses pada tanggal 20 Januari 2015 pukul 19.30 